\title{
The Effect of Inquiry-based Learning on Religious Subjects Learning Activities: An Experimental Study in High Schools
}

\author{
Husni \\ Institut Agama Islam Darussalam (IAID) Ciamis, Jawa Barat \\ E-mail: husni1967@yahoo.co.id
}

Received: January 2, 2020 | Accepted: May 11, 2020

\begin{abstract}
This study aims to test the validity of inquiry learning models in making students more active in the learning process. This research using experimental methods. The experimental design uses a pretest and posttest control group, an experimental design with two groups. Research has proven that the inquiry learning model significantly makes students more active. They become more responsive, more enthusiastic, ask more questions, and are happier to find new knowledge. The group of students who learned using the inquiry learning model had higher student activities compared to the group of students who did not use the inquiry learning model. The first group of students became more diligent, more enthusiastic, asked more questions, more active in discussion group, and more creative in solving problems and finding new knowledge.
\end{abstract}

\begin{abstract}
Abstrak
Penelitian ini bertujuan untuk menguji validitas model pembelajaran inkuiri dalam meningkatkan tingkat keaktifan siswa proses pembelajaran. Penelitian ini menggunakan metode eksperimen. Desain eksperimental menggunakan control group pretest and posttest, suatu desain eksperimental dengan dua kelompok, kelompok eksperimen dan kelompok kontrol. Penelitian ini berhasil membuktikan signifikansi model pembelajaran inkuiri dalam meningkatkan tingkat keaktifan siswa proses pembelajaran. Mereka menjadi lebih responsif, lebih antusias, lebih aktif bertanya, dan lebih senang menemukan pengetahuan baru. Aktivitas belajar kelompok siswa yang belajar menggunakan model pembelajaran inkuiri lebih tinggi dibandingkan dengan kelompok siswa yang tidak menggunakan model pembelajaran ini.
\end{abstract}




\section{Keywords}

Inquiry-based learning, active learning, religious subjects

\section{Introduction}

The process of learning "religious subjects" is often seen to be passive, meaning that students do not respond when religious teachers deliver learning stimuli. During the religious learning process, students appear to be passive and less enthusiastic. The students do not respond to stimulation or stimulation provided by the teacher. Different conditions are seen when students carry out learning activities in "general" subjects, where students appear to be more active and more enthusiastic. The classroom atmosphere in the learning activities of "general" subjects seems more lively and vibrant. More students are asking questions and have the initiative to respond to questions from the teacher.

This fact is thought to be caused by the learning model implemented by the teacher being less attractive. Learning activities in religious subjects use more teacher-centered learning models with the lecture method as the main method. The lecture method is a one way communication. Because communication is one-way, it is natural for students to become less active.

Theoretically, the cause of students' inaction in the learning process can be caused by some complex factors. These factors can come from students, from teachers, from subjects, from the learning models used, as well as from the classroom and school environment. Inactivity that comes from student factors can be caused by students having mental and physical disorders. Mental or psychological disorders experienced by students can come from problems with family, friends, or even issues with themselves while physical disruption can occur because students experience pain that is not realized and is not known by the students themselves, their families, as well as their friends and teachers.

Inactivity of students from teacher factors can occur if the presence of a teacher in the class is not expected by students because the learning activities carried out by the teacher saturate. Besides, factors related to this teacher can also be caused by the teaching style of the teacher being unattractive, boring, or even frightening. The teacher, as a class leader during the learning process, is very likely to show leadership that does not inspire students to act actively. Teacher leadership in the classroom may not be authoritarian, easily offended, and does not provide an opportunity for students to have their own opinions. 
Inactivity originating from a subject can occur if the subject is followed by students is too difficult or even too easy so it does not stimulate student enthusiasm for learning. Also, student inactivity can be caused students to consider the subject matter to be insignificant so that students' attitudes and learning behaviors during the course are not severe, trivial, and careless. The next factor that causes students to be less active in the classroom environment and the school environment. If schools apply stringent rules, this condition can cause fear in students. As a result, students feel shackled and feel afraid to think according to their beliefs and knowledge. If the classroom and school environments are not conducive due to limited facilities and infrastructure, this can also lead to less active learning activities.

But from the factors that cause students to be inactive during the learning process, the element of using the learning model is believed to be an essential factor. The use of appropriate learning models can encourage students to be more active and more enthusiastic. By using the right learning model, learning activities will not only encourage students to be more active, but can create a learning process that is creative, effective, and fun (DePorter \& Hernacki, 2007).

Active learning means that in the learning process, the teacher can create an atmosphere such that students actively ask questions, question, and express ideas (Mehrotra, 2009). It's because the learning process is an active process of the learner in building knowledge, not a passive method that only accepts teacher lectures about knowledge. If learning does not provide an opportunity for students to play an active role, then learning is contrary to the nature of learning (Husni, Setiawan, Azis, Tantowie, \& Rizal, 2020b). The active role of students is very important in the context of forming a creative generation, which is able to produce something for the benefit of himself and others.

One learning model that conceptually can realize active learning is the inquiry learning model. The inquiry learning model has a closeness of meaning to the discovery model. Inquiry or discovery is a mental process in which students assimilate a concept or a principle. Mental processes, for example, observing, explaining, grouping, making conclusions, and so on. Inquiry can also be seen as an extension of discovery (Husni, 2016). That is, inquiry contains a higher level of mental processes. Using the inquiry approach means to teach students to control situations faced when dealing with the physical world by using techniques used by researchers. Approach inquiry is divided into guided inquiry and free inquiry or open inquiry. The difference between the two lies in who asks the question and what is the purpose of the activity. For example, they are formulating problems, designing experiments, carrying out investigations, collecting data, analyzing data, making conclusions, and so 
on. This study aims to test the validity of inquiry learning models in making students more active in the learning process.

\section{Literature Review}

\section{The Concept of Active Learning}

Etymologically, "activity," which comes from the word "active" means active, dynamic, powerful (static or slow opponent). The term active means meaningful activity or busyness. While terminologically, more active learning refers to an "active" learning pattern. Active learning is a perspective that considers learning as an activity to build meaning or understanding of experience and information, which is carried out by the learner, not by the instructor, and considers teaching as an activity to create an atmosphere that develops the learner's initiative and learning responsibilities so that he wishes to continue to learn throughout their lives and not depend on the teacher/other people if they learn new things (Mehrotra, 2009).

Active learning can also be interpreted as a learning process in which the teacher creates an atmosphere in such a way that students actively ask, question, and express ideas, because the learning process is an active process of the learner in building his knowledge, not a passive process that only accepts teacher lectures about knowledge (Braxton, Milem, \& Sullivan, 2000). According to L. Dee Fink (Fink, 1999), active learning consists of two main components, namely: the element of experience (experience), including activities (doing) and observation and dialogue, including dialogue with oneself and conversation with others. Dialogue with self is a form of learning in which students think reflectively about a topic. They ask themselves what they are or should be thinking about how feel from the point they are studying. They are thinking about their own thinking, in a broader range of questions, and not only related to cognitive aspects alone (Fink, 1999). Dialogue with others occure, when students read textbooks or listen to lectures, they are basically having a dialogue with "listening" from others (teacher, book writer), but their nature is very limited because in it there is no feedback and exchange of thoughts. L. Dee Fink called it "partial dialogue" (Fink, 1999). Another form of more dynamic dialogue is to divide students into small groups, where students can discuss topics of learning intensively (Boyer, 2002). More than that, to involve students in certain dialogue situations, the teacher can develop creative ways, for example inviting students to dialogue with practitioners, experts, and so on, both that take place in the classroom or outside the classroom, through direct interaction or in written. The observing activity occurs where students can see and listen when other people doing something, 
related to what they are learning (Boyer, 2002). For example, observing a teacher doing something. For example, religious teachers who are demonstrating how to pray correctly, computer teachers who are learning how to browse on the internet, and so on. In addition to watching the teacher's demonstration, students can also be invited to listen and see from other people, for example watching performances on how to misplace the body, watching a musician demonstrate his skills in playing certain instruments, and so on. Likewise students can be invited to observe other phenomena, related to the topic being studied, for example natural, social, or cultural phenomena.

\section{The Concept Inquiry-based Learning Model}

The inquiry learning model is one of the learning models in the world of education. Etymologically, the inquiry comes from the word 'to inquire' (Bonnie, 1988), which means taking part, or being involved, in asking questions, seeking information, and conducting investigations. Inquiry can be defined as a search for truth, information, or knowledge by questioning and making efforts to answer the question in question (Eastwell, 2009). Peter Eastwell and Ann Haley MacKenzie define that inquiry is a human effort to explain phenomena that arouse curiosity [10] rationally. In other words, the inquiry is related to active activity and knowledge-seeking skills to satisfy curiosity.

The inquiry learning model is a series of learning activities that emphasize the process of thinking critically and analyzing to find and find answers for themselves on a problem in question (Kuhn, Black, Keselman, \& Kaplan, 2000). According to Piaget (Suparno, 2008) inquiry learning model is a learning model that prepares students in situations to conduct their own experiments widely in order to see what is happening, want to do something, ask questions, and find the answers themselves, and connect the findings of one with the other conclusions, compare what is found with what other students found. Several things are the main characteristics of the inquiry learning model. First, the inquiry model emphasizes maximum student activity to search and discover, meaning that the inquiry approach places students as subjects of learning. In the learning process, students not only act as recipients of the lesson through verbal explanations by the teacher, but they also have a role in finding their own core of the subject matter itself. Second, all activities undertaken by students are directed to find and find themselves from something that is questioned, so that it is expected to foster an attitude of confidence (self-belief). This means in the inquiry approach, the teacher is placed not as a learning resource, but as a facilitator and motivator for student learning. Learning activities are usually done through a question and answer 
process between the teacher and students, so the teacher's ability to use questioning techniques is a critical requirement in conducting an inquiry. Third, the purpose of using inquiry learning models is to develop intellectual abilities as part of mental processes. Consequently, in inquiry learning, students are not only required to master the lesson but how they can use their potential (Bevevino, Dengel, \& Adams, 1999).

Inquiry-based learning, sometimes called inquiry-based instruction, is learning that uses scientific steps as a learning scenario (Siberman, 2009). This learning model is directed so students master of the concept of knowledge through efforts to answer questions. Efforts are made through the process of exploration, data processing, and drawing conclusions. Basically, inquire is a behavior that is closely attached to human nature. Everyone conducts an inquiry process from birth to death. It was authentic, even though I didn't realize it. A baby, for example, runs an inquiry when it recognizes an approaching face, holds an object, places an item in the mouth, and looks at the sound. In their minds, questions always arise and are followed by efforts to answer them. When a four-year-old child sees a toy, he is eager to know what the toy is like and always wants to unpack it to find out. There are rarely durable toys. As the age of the child increases, more and more questions about phenomena are encountered in everyday life. Unfortunately, as children grow older, attempts to answer concerns and limitations hamper questions. When a 12-year-old student wants to know why television can display live images, they are struck by the limited ability and means to find out. When this happens often, the ability to make inquiries in children is less developed to adulthood.

\section{Methods}

This research was conducted at the Senior High School (SMA Plus) Darussalam Ciamis, West Java, Indonesia. This study using experimental methods. The experimental design used was a control group pre and posttest or experimental design using two groups (the experimental group and the control group). Both groups were given two tests (pretest and posttest). Before the experimental activities were carried out, the two groups (the experimental group and the control group) each measured their level of activity (pretest) in religious studies. After 2-3 months of experimental activity took place, the two groups again measured the level of activity (posttest).

During the experimental process, researchers also made observations on student learning activities. The data obtained through observation during the experiment takes place as additional data to complete the primary data obtained through the pretest and posttest. 


\section{Results And Discussion}

From the results of observations of the experimental group before the treatment (treatment) was obtained experimental group pretest data as seen in table 1 and table 2 below:

Table 1. Descriptive Statistical Scores for the Level of Activity of Two Groups Before the Experiment

\begin{tabular}{lrr}
\hline \multicolumn{1}{c}{ Descriptive Statistics } & \multicolumn{1}{c}{ EG } & \multicolumn{1}{c}{ CG } \\
\hline Mean & 98.52 & 98.37 \\
Median & 98.00 & 98.00 \\
Minimum & 94.00 & 94.00 \\
Maximum & 105.00 & 105.00 \\
Variance & 8.63 & 6.00 \\
Standard Deviation & 2.94 & 2.45 \\
\hline EG = Experimental Group; CG $=$ Control Group
\end{tabular}

The table shows that (a) the average score of the experimental group pretest was 98.52; (b) the median or middle value is 98; (c) the smallest (minimum) pretest score is 94; (d) the maximum value (maximum) pretest score is 105; (e) pretest score variance is 8.63 ; and (f) the standard deviation is 2.94. Meanwhile, the results of observations of the control group before the experiment (treatment) were obtained the control group pretest data as follows (a) the average score of the control group pretest was 98.37; (b) the median or middle value is 98; (c) the smallest (minimum) pretest score is 94; (d) the maximum value (maximum) pretest score is 105; (e) pretest score variance is 6.00; and ( $\mathrm{f}$ ) the standard deviation is 2.45 .

Table 2. Descriptive Statistical Scores for the Level of Activity of Two Groups After the Experiment

\begin{tabular}{lrr}
\hline \multicolumn{1}{c}{ Descriptive Statistics } & \multicolumn{1}{c}{ EG } & \multicolumn{1}{c}{ CG } \\
\hline Mean & 113.48 & 98.84 \\
Median & 117.00 & 99.00 \\
Minimum & 104.00 & 95.00 \\
Maximum & 126.00 & 103.00 \\
Variance & 38.97 & 4.14 \\
Standard Deviation & 6.24 & 2.03 \\
\hline EG = Experimental Group; CG $=$ Control Group
\end{tabular}


After the experimental and treatment activities were given to the experimental group by applying the inquiry learning model, it was obtained that the more active learning posttest data in religious learning as follows (a) the average posttest score of the experimental group was 113.48; (b) the median or middle value is 117 ; (c) the smallest (minimum) posttest score is 104; (d) the maximum value (maximum) pretest score is 126; (e) posttest score variance is 38.97; and ( $\mathrm{f}$ ) the standard deviation is 6.24. Meanwhile, after the experimental activities were carried out where the conventional learning model was used for the control group, the data of the more active learning posttest were obtained in religious learning as follows (a) the average score of the posttest control group was 98.84; (b) the median or middle value is 99; (c) the smallest (minimum) score of the control group posttest is 95; (d) the highest score (maximum) posttest score is 103; (e) posttest score variance is 4.14; and (f) the standard deviation is 2.03 .

Table 3. Hypothesis Tests Results

\begin{tabular}{lrl}
\hline Statistics & \multicolumn{1}{c}{ Scores } & \multicolumn{1}{c}{ Results } \\
\hline t-value & 19.25 & The null hypothesis is \\
t-table & 1.6973 & rejected, and the \\
$d f$ & 32 & working hypothesis is \\
Sig. & 0.0000 & accepted. \\
\hline
\end{tabular}

The hypothesis being tested is, "The application of inquiry learning models has an effect on more active learning in religious subjects." The testing of this hypothesis uses the T-Test for Two Paired Variables because the necessary requirements are met, namely, the two variables are normally distributed.

From the SPSS output obtained, it is known that the value of $\mathrm{t}$ is 19.25 (minus sign [-] is ignored) and $d f 32$ with a probability value (Sig.) of 0,000 . T-value of 19.25 is called t-count. Furthermore, this t-count will be compared with the $\mathrm{t}$-table value. The provisions for drawing conclusions are: If $\mathrm{t}$-count is greater than t-table, then the null hypothesis is rejected, and the working hypothesis is accepted. Conversely, if the t-count is smaller than t-table, then the null hypothesis is accepted, and the working hypothesis is rejected. With $\mathrm{df}$ $=32$ and $\alpha=0.05$, the value of the table is 1.6973 . Because the value of $t-$ count (19.25) is far greater than t-table (1.6973), the null hypothesis is rejected, and the working hypothesis is accepted. So, it is proven that the inquiry learning model can make students more active in learning religious lessons in SMA Plus Darussalam, Ciamis, West Java, Indonesia. 
The results showed that the inquiry learning model could significantly make students more active in the learning process of religious subjects. The question is why the inquiry learning model can significantly increase student activity in learning? This is because the inquiry learning model has a number of advantages. First, the inquiry learning model is a learning model that emphasizes the development of cognitive, affective, and psychomotor aspects in a balanced manner so that learning through this model is considered to be more meaningful. Second, inquiry learning models can provide space for students to learn according to their learning styles. Third, the inquiry learning model is a learning model that is considered following the development of modern psychology that regards learning as a process of behavior change thanks to experience. Fourth, inquiry learning models can serve the needs of students who have above average abilities, meaning that students who have good learning abilities will not be hampered by students who are weak in learning.

Fifth, by using the inquiry learning model, learning becomes more alive and can make students active. Sixth, inquiry learning models can shape and develop fundamental concepts to students. Seventh, inquiry learning models can help in using memory and transfer to new learning process situations. Eighth, inquiry learning models can give students sufficient time so that they can assimilate and accommodate the information.

Ninth, the inquiry learning model encourages students to think and work on their own initiative, to be honest, objective, and open. Tenth, by using the inquiry learning model, it can avoid the traditional way of learning, namely the teacher who masters the class. Eleventh, inquiry learning models allow students to learn by utilizing various types of learning resources. Twelfth, the inquiry learning model can train students to learn on their own positively so as to develop democratic education (Husni \& Bisri, 2020; Husni, Bisri, Tantowie, Rizal, \& Azis, 2020). With these advantages, the inquiry learning model can effectively increase student learning activities (Bisri \& Husni, 2020; Husni, Setiawan, Azis, Tantowie, \& Rizal, 2020a). In addition, this learning model is also believed to be able to encourage students to think scientifically and in solving the problems they face.

\section{Conclusion}

This research proves that the inquiry learning model significantly makes students more active. They become more responsive, more enthusiastic, ask more questions, and are happier to find new knowledge. The group of students who learned using the inquiry learning model had higher student activities 
compared to the group of students who did not use the inquiry learning model. The first group of students became more diligent, more enthusiastic, asked more questions, were more active in discussion activities, and were more creative in solving problems and finding new knowledge.

\section{REFERENCES}

Bevevino, M. M., Dengel, J., \& Adams, K. (1999). Constructivist Theory in the Classroom: Internalizing Concepts through Inquiry Learning. The Clearing House, 72(5), 275-278.

Bisri, H., \& Husni, H. (2020). The Influence of Teacher's Multicultural Awareness on "Santri" Learning Activities. Journal of Critical Reviews, 7(7), 133-138. https://doi.org/10.31838/jcr.07.07.21

Bonnie, W. (1988). Classroom Inquiry: Learning about Learning. The English Journal, 77(2), 30-33.

Boyer, K. R. (2002). Using Active Learning Strategies to Motivate Students. Mathematics Teaching in the Middle School, 8(1), 48-51.

Braxton, J. M., Milem, J. F., \& Sullivan, A. S. (2000). The Influence of Active Learning on the College Student Departure Process: Toward a Revision of Tinto's Theory. The Journal of Higher Education, 71(5), 569-590.

DePorter, B., \& Hernacki, M. (2007). Quantum Learning: Membiasakan Belajar Nyaman dan Menyenangkan. Bandung: Mizan.

Eastwell, P. (2009). Inquiry Learning. The American Biology Teacher, 71(6).

Fink, L. D. (1999). Active Learning. New York: Wardswart Publishing Company.

Husni. (2016). The Challenges of Religious Education in Indonesia and the Future Perspectives. Religious Studies: An International Journal, 4(2). Retrieved from https://fssh-journal.org/index.php/jrs/article/view/12

Husni, H., \& Bisri, H. (2020). The Indonesian-Moderate Muslim Communities Opinion on Social Media Hate Speech. International Journal of Psychosocial Rehabilitation, 24(8). https://doi.org/10.37200/IJPR/V24I8/PR281083 
Husni, H., Bisri, H., Tantowie, T. A., Rizal, S. S., \& Azis, A. (2020). Religious Community Responses to COVID19: Case Study on Muslim Small Community. International Journal of Psychosocial Rehabilitation, 24(8). https://doi.org/10.37200/IJPR/V24I8/PR281038

Husni, Setiawan, I., Azis, A., Tantowie, T. A. J., \& Rizal, S. S. (2020a). Validity and reliability of multicultural competency instruments for islamic education teachers. International Journal of Scientific and Technology Research, 9(2).

Husni, Setiawan, I., Azis, A., Tantowie, T. A. J., \& Rizal, S. S. (2020b). Validity and Reliability of Multicultural Competency Instruments for Islamic Education Teachers. International Journal of Scientific \& Technology Research, 9(2). Retrieved from http://www.ijstr.org/paperreferences.php?ref=IJSTR-0220-30941

Kuhn, D., Black, J., Keselman, A., \& Kaplan, D. (2000). The Development of Cognitive Skills to Support Inquiry Learning. Cognition and Instruction, 18(4), 495-523.

Mehrotra, C. (2009). Aging and Diversity: An Active Learning Experience. New York: Routledge Taylor \& Francis Group.

Siberman, M. (2009). Pembelajaran Aktif. Kualalumpur: Institut Terjemahan Negara Malaysia Berhad.

Suparno, P. (2008). Teori Perkembangan Kognitif Jean Piaget. Yogyakarta: Kanisius. 
